\title{
Identification of High School Student's Career Preference with the Logistics Model
}

\author{
Andhita Dessy Wulansari, Kumaidi, Samsul Hadi \\ \{andhita.dessy2015@student.uny.ac.id ${ }^{1}$,kum231@ums.ac.id², Samsul_hd@uny.ac.id ${ }^{3}$ \} \\ Department of Educational Research and Evaluation, Graduate School of Yogyakarta State \\ University, Sleman, Indonesia ${ }^{1}$, Department of Psychology, Muhammadiyah University of Surakarta, \\ Surakarta, Indonesia ${ }^{2}$, Department of Electronics Engineering Education, Yogyakarta State University, \\ Sleman, Indonesia ${ }^{3}$
}

\begin{abstract}
The aim of education is to develop students' potential according to their interests and talents. Students' potential and talent need to be detected early so that schools can direct students to choose majors in the university or higher education and eventually select careers that suit their interests and talents. Holland's Personality Theory is the most frequently used theory to study the phenomenon of career preference. The focus of this research is to analyze the career preference of high school students based on Holland's Personality Type. For the analysis, the researchers applied multinomial logistic regression analysis with consideration to the nominal data scale of Holland students' personality types, namely realistic, investigative, artistic, social, enterprising, and conventional. Based on the results of the analysis, it can be concluded that majority of the students have enterprising and artistic personality types. Further, the factors that significantly influence the differences in Holland's Personality Type are the student's major in high school, gender, parents' educational background, parents' income, and parents' occupation.
\end{abstract}

Keywords: interest, career, holland, personality, logistics

\section{Introduction}

Ideology of gender is still dominating Indonesian culture and thus create a patriarchal culture, where most of Indonesian people think that men are superior to women. In Indonesian culture, gender differences become the consideration in the distribution of work, which lead to different treatments as well. Women are usually expected to do works that require accuracy and patience, while the men are usually expected to work with physical strength. Therefore, the boys are told to conform to the common standard of being manly such as being brave and never cry, while girls are told to be gentle and submissive [1] [2] [3] [4]. This culture is what creates differences in work between men and women [5] [6] [7] [8]. Gender differences in work has negative implications, because it ignores ability of the individual. Gender stereotypes related to masculinity and femininity can inhibit development, affect one's behavior and perceptions of others and raise problems of gender inequality [9].

Selection of career based on gender may not suit one's personality typology. This can later have a negative impact which may lead to difficulties of achieving success in their careers. However, when someone select career in accordance with personality, in general they will be more successful in their career, because the work feels more enjoyable. Suitability is what makes people more loving and happier with their work, so they can work harder and be more 
responsible. There is a significant relationship between personality and job satisfaction [10]. Personality typology greatly affect students' selection of interests [11] [12] [13] [14]. Therefore, education has the aim to develop students' abilities and potential according to their own interests and talents. The development of students' potential and talent needs to be detected early so that the school can direct students to choose education and career path which suit their personalities and interests best. Personality is an important element in achieving one's success.

Holland's Personality Theory is the most widely used theory to study the phenomenon of career selection that supports individual success. Individuals who have a career that matches their personality will have a long, healthy and happy work period [15]. This is because people who have the same interests in the work environment will have the same personality [16]. The main focus of Holland's theory is based right on the understanding of vocational behavior to establish a practical way to help young people to start their career. Holland's types of personality are the result of the interaction of innate and environmental factors. The types are realistic, investigative, artistic, social, enterprising, and conventional.

The description above shows the importance of knowing students' interest in accordance with their personalities, since there are many students who change their majors after entering college because they do not feel comfortable with the major [17] [18]. Therefore, the focus of this study is to analyze the career interests of high school students based on Holland's personality type with specific objectives: (1) Identifying the characteristics of students' career interests based on Holland's Theory; (2) Analyzing the model of student career interest development according to Holland Theory Modeling which is based on supporting demographic factors; and (3) Analyzing the accuracy of career interest classifications generated by multinomial logistic regression model.

\section{Related Works}

\subsection{Interest}

An interest is a voluntary feeling of liking and being interested in an object or an activity. According to Holland, interest is a high tendency of feeling towards something [19]. In addition, interest can be defined as a mental device consisting of a combination, fusion, and mixture of feelings such as prejudice, anxiety, fear and other tendencies that can direct individuals to a particular choice [20]. Based on the definitions, it can be understood that the interest referred to in this study is the tendency of the heart to an activity that encourages individuals to choose or to plan certain major/department leading to the profession or occupation.

\subsection{Factors of Career Selection}

There are two factors that influence the preference on a career, namely internal and external factors [21]. These internal factors are : (1) Life values, which means some ideals pursued by a person everywhere and at any time ; (2) The level of intelligence, which means the level of ability to obtain an achievement; (3) Special talents, which is the abilities that stand out in certain business fields; (4) Interest, which is the tendency of a person to feel attracted to a certain field and to feel happy when participating in it; (5) Traits, which is the personality traits that make a person unique; (6) Knowledge, which is the possessed information regarding the work field and oneself; (7) Physical state, which is a physical characteristic of a person . 
External factors are : (1) Society, which is the social and cultural environment in which a person is raised, (2) Social state and status of an area and a family, which is the rate of economic growth and community stratification of a group; (8) Family, which means the expectation of the family for education and occupation; (9) School education, which is the views and attitudes of the teaching staff towards their students regarding the values contained in certain occupations; (10) Peers, which is the views and hopes regarding the future which are implied in everyday interaction; (11) Demands attached to a career, which means if a person wish to obtain qualifications in a certain specification, they must fulfill a number of requirements. In addition, other influential factors are intellectual ability, talent, influence of education, family, personality, self-concept and self-esteem, virtues, interests, ideals and reality, images and expectations, gender differences, and environmental influences [22] [23] [24] [25]. The conformity between one's personality and characteristics of a person's work environment also affect a person's career preference [26] [27] [28] [29].

\subsection{Holland's Personality Typology}

Typology is the study that classifies humans based on certain factors. Personality is the dynamic organization within the individual on the psychophysical system that determines the unique adaptation to the environment [30]. Thus, the human personality typology is based upon the classification of dynamic organization within the individual on the psychophysical system which determines the adaptation to the environment. The personality pattern here is a representation of the personality type that results from individual response to the instrument.

According to Holland, there are 6 personality typologies and each suit to their interests: (1) Realistic Type, whose preference is for activities that require explicit, orderly, or systematic manipulation of objects, tools, machines, and animals. The implementation of this concept means that individuals of this type tend to dislike activities that provide assistance (service) or education. Individuals of this type consider themselves both mechanical and athletic and not capable of social skills and human relationships; (2) Investigative type, which prefers activities that require observational, symbolic, systematic, and creative investigations into physical, biological, and cultural phenomena in order to understand and control the phenomenon, and dislike persuasive, social. and repetitive activities. Some occupations that suit the investigative type individuals well are chemists and physicists; (3) Artistic type, which prefers activities that are diverse, free, and not systematized to create artistic products, such as paintings, dramas, proses. People with this type do not like systematic, regular and routine activities. Some of its special characteristics are emotional, imaginative, impulsive and pure. Artistic occupations are usually related to painting, written arts, acting, and sculpture; (4) Social types, which prefer activities involving others with an emphasis on activities to help, teach, or provide assistance. People of this type do not like routine and systematic activities involving inanimate objects and stuffs. Some of its special characteristics are cooperation, friendliness, persuasiveness and being wise. Social occupations include jobs such as teaching, counseling, and social welfare work; (5) Enterprising type, which prefer activities that involve manipulation of others for financial (economic) benefits or organizational goals. People of this type do not like systematic, abstract, and scientific activities. These people think that they are aggressive, popular, confident, and has the ability to lead. They highly value the success in politics and economics. The characteristics are ambition, dominant, optimism and sociability; and (6) Conventional types prefer activities that require explicit, regular and systematic data manipulation in order to contribute to organizational goals. These people do not like activities that are uncertain, free and not systematic. Their competencies are developed in the field of clerical, computational, and 
business systems. They do not pay attention to artistic activities. Some typical features are efficiency, regularity, practicality, and self-control. The suitable occupations are bankers, price assessors, tax experts and bookkeepers.

\subsection{Multinomial Logistics Regression}

Multinomial logistic regression is an extension of logistic regression with a binary response that can handle variables with more than two categories. For a regression model with threecategories-nominal-scale response variables, it utilizes $3 \mathrm{Y}$ variable categories which are encoded into 0,1 , and 2 [31]. The Y variable is parameterized into two logit functions. The response categories which is used as the comparison need to be determined beforehand. In general, $\mathrm{Y}=0$ is used as a comparison. To form the logit function, $\mathrm{Y}=1$ and $\mathrm{Y}=2$ are compared to $\mathrm{Y}=0$. The form of logistic regression model in the form of an opportunity function with $\mathrm{p}$ as predictor variables as in the following equation.

$$
\pi(X)=\frac{\exp \left(\beta_{0}+\beta_{1} X_{1}+\beta_{2} X_{2}+\ldots+\beta_{p} X_{p}\right)}{1+\exp \left(\beta_{0}+\beta_{1} X_{1}+\beta_{2} X_{2}+\ldots+\beta_{p} X_{p}\right)}
$$

Logit transform will produce two logit functions as follows, by specifying that $\mathrm{X} 0=1$.

$$
\begin{aligned}
& g_{1}(X)=\ln \left[\frac{P(Y=1 \mid X)}{P(Y=0 \mid X)}\right]=\beta_{10}+\beta_{11} X_{1}+\beta_{12} X_{2}+\ldots+\beta_{1 p} X_{p}=X^{T} \beta_{1} \\
& g_{2}(X)=\ln \left[\frac{P(Y=2 \mid X)}{P(Y=0 \mid X)}\right]=\beta_{20}+\beta_{21} X_{1}+\beta_{22} X_{2}+\ldots+\beta_{2 p} X_{p}=X^{T} \beta_{2}
\end{aligned}
$$

Based on the two logit functions, the probability of response or multinomial logistic regression model is obtained with three-categories-nominal-scale response variables as follows [12].

$$
\begin{aligned}
& \pi_{0}(X)=\frac{1}{1+e^{g_{1}(X)+g_{2}(X)}} \\
& \pi_{1}(X)=\frac{e^{g_{1}(X)}}{1+e^{g_{1}(X)+g_{2}(X)}} \\
& \pi_{2}(X)=\frac{e^{g_{2}(X)}}{1+e^{g_{1}(X)+g_{2}(X)}}
\end{aligned}
$$

\section{Material And Methodology}

\subsection{Types of research}

The research is a quantitative research because it emphasizes on numerical data which are processed with statistical methods. The data are collected using questionnaires adopted from the Holland Personality Typology questionnaire. Each item contains questions about students' preference for certain career fields. The objective of this study is to describe the statistics and to test a (inferential) theory. Descriptive statistics are used to identify students' personality types based on Holland's theory, while inferential analysis is used to test career development models based on Holland's personality typology using multinomial logistics regression analysis. 


\subsection{Research Sites and Subjects}

The study was conducted in Assalaam Surakarta High School which is a formal education school in the concept of Modern Islamic Boarding School education under the Islamic Studies Council Foundation of Surakarta, with the research subjects being all Assalaam high school students in class XII on 2015/2016 academic year, which are divided into natural and social science studies majors with the number of students as many as 264 people.

\subsection{Data Collection Instrument}

As previously stated, the data was collected using a questionnaire adopted from the Holland Personality Typology questionnaire consisting of 48 items. Statement items are developed from 6 Holland personality types as shown in the following table.

Table 1. Instrument Guideline

\begin{tabular}{lc}
\hline \multicolumn{1}{c}{ Personality Type } & Item Number \\
\hline Realistic & $1,7,13,19,25,31,37,43$ \\
Investigative & $2,8,14,20,26,32,38,44$ \\
Artistic & $3,9,15,21,27,33,39,45$ \\
Social & $4,10,16,22,28,34,40,46$ \\
Enterprising & $5,11,17,23,29,35,41,47$ \\
Conventional $\quad$ Total items & $6,12,18,24,30,36,42,48$ \\
\multicolumn{2}{c}{$\mathbf{4 8}$ items } \\
\hline
\end{tabular}

Each item is measured using a Likert scale with 5 alternative choices. The score for each answer option is as follows.

$\begin{array}{ll}\text { Very Dislike }=1 & \text { Like }=4 \\ \text { Dislike }=2 & \text { Very Like }=5\end{array}$

Neutral $=3$

\subsection{Research variable}

Apart from those data, this research also collected data from some variables which are suspected as a factor causing an individual to have a certain type of Holland personality, namely: Majors of studies (Natural Science $=1$ and Social Science $=2$ ); Gender (Female $=1$ and Male $=2)$; The last education taken by father/mother $(\operatorname{SD}$ (elementary) $=1, \operatorname{SMP}($ junior high $)=2$, SMA $($ senior high $)=3, \mathrm{D} 3=4, \mathrm{~S} 1=5, \mathrm{~S} 2=6)$; Father + mother's income per month $(<1$ million $=1,1-2.5$ million $=2 ; 2.5-5$ million $=3,>5$ million $=4)$; The main occupation of parents (PNS $($ Civil Servant $)=1$; Non-Civil-Servant Lecturer / Teacher $=2$; Non-Civil-Servant Doctor $/$ Nurse $=3$; Police = 4; State-Owned Enterprise employee = 5; Non-State-Owned Enterprise employee $=6 ;$ Lawyer $=7$; Accountant $=8 ;$ Contractor $=9 ;$ Sailor $=11$; Entrepreneur $=12$; Farmer $=13$; Other $=15$.

\subsection{Data analysis technique}

The data analysis technique used was descriptive and inferential statistical analysis with multinomial logistic regression analysis. It is important to note that the response variable was nominal scale with six categories, thus the 6 categories of $Y$ outcome variables were encoded into $0,1,2,3,4$, and 5. Furthermore, Y variable was parameterized into five logit functions. 
The steps in data analysis which are carried out to answer the research objectives are:

1. Perform descriptive statistical data analysis to determine the characteristics of the Holland personality type of the students (respondents) which include deoendent/response (Y) variables and independent/predictors variables $\left(\mathrm{X}_{1}, \mathrm{X}_{2}, \mathrm{X}_{3}, \mathrm{X}_{4}, \mathrm{X}_{5}, \mathrm{X}_{6}\right.$, and $\left.\mathrm{X}_{7}\right)$ by looking at the frequency and percentage of each variable category.

2. Make a multinomial logistic regression model to get the factors that influence the holland personality type of the students (respondents) using SPSS software, and the following steps.

a. Conduct independence test between response variables $(\mathrm{Y})$ and predictor variables $\left(\mathrm{X}_{1}\right.$, $\mathrm{X}_{2}, \mathrm{X}_{3}, \mathrm{X}_{4}, \mathrm{X}_{5}, \mathrm{X}_{6}$, and $\mathrm{X}_{7}$ ).

b. Perform individual multinomial regression analysis on the response variable (Y) with predictor variables that have a relationship with the response variable based on the independence test. In this study the categories of response variables used as comparison are conventional personality types, so that there are five logit functions, where logit function 1 is for realistic types, logit function 2 is for investigative type, logit function 3 is for artistic type, logit function 4 is for social type function and logit function 5 is for enterprising type.

c. Conduct simultaneous multinomial regression analysis.

d. Interpret the odds ratio value.

e. Interpret the model simultaneously and calculate the accuracy of the model classification.

\subsection{Instrument Validity dan Reliability}

Proofing of instrument validity and reliability needs to be done in this study because the instrument used is an instrument adopted from the Holland Personality Typology questionnaire. The validity measured in this study is content validity. The measurement of content validity using the Lawshe's CVR (Content Validity Ratio) method. This study involved 7 people as raters by choosing one of 3 answers, namely: accepted, accepted with review and rejected. If the obtained CVR coefficient/index is greater than the CVR minimum score (minimum value) thus the question item used has fulfilled the validity of the content (valid). After revising several times, there were 48 items which were valid.

Instrument reliability was measured by following the Alpha Cronbach coefficient concept on six personality type constructs. Instrument reliability was analyzed using SPSS software by calculating the instrument reliability partially and completely using Cronbach Alpha. Each construct was said to be reliable with an Alpha coefficient of at least 0.7. Details of the reliability analysis results of each construct is as follows:

Table 2. Reliability Of Each Construct

\begin{tabular}{lcl}
\hline \multicolumn{1}{c}{ Construct } & Coefficient Alpha & Criteria \\
\hline Realistic & 0.798 & Reliable \\
Investigative & 0.832 & Reliable \\
Artistic & 0.763 & Reliable \\
Social & 0.701 & Reliable \\
Enterprising & 0.729 & Reliable \\
Conventional & 0.842 & Reliable \\
\hline
\end{tabular}

To calculate the overall (total) reliability using the following formula: 


$$
\begin{gathered}
\alpha_{\text {strat }}=1-\frac{\sum \sigma_{i}^{2}\left(1-\alpha_{i}\right)}{\sigma_{x}^{2}} \\
\alpha_{\text {strat }}=1-\left(\frac{36.596(1-.798)+51.398(1-.83)+42.85(1-.76)+29.169(1-.70)+31.338(1-.729)+46.98(1-.84)}{563.688}\right) \\
\alpha_{\text {strat }}=0.9099
\end{gathered}
$$

From the calculation of overall reliability, it is showed that the overall reliability of the construct has a reliability level of 0.9099 , thus the instrument is categorized as reliable.

\section{Result And Discussion}

\subsection{Characteristics of High School Students}

The categories of characteristics were based on Holland's Personality Type, which are majors of studies in high school, student's gender, father's education, mother's education, parent's income, father's occupation, and mother's occupation.

Table 3. Characteristics Of Respondents

\begin{tabular}{lc}
\hline \multicolumn{1}{c}{ Personality Type } & Percentage \\
\hline Realistic & $3.8 \%$ \\
Investigative & $13.6 \%$ \\
Artistic & $22.0 \%$ \\
Social & $18.9 \%$ \\
Enterprising & $24.2 \%$ \\
Conventional & $17.4 \%$ \\
\hline
\end{tabular}

Based on Table III, it can be seen that the majority of respondents have enterprising and artistic personality types, consecutively as much as $24.2 \%$ and $22 \%$. Enterprising types are characterized to be ambitious, dominating, optimistic, and sociability. The individuals appear to be aggressive, popular, confident and have the ability to lead. People of this type do not like activities which are systematic, abstract, and scientific. They highly value the success in politics and economics. Meanwhile, people of Artistic Type prefer such activities which are various, and free. They do not like systematic, regular and routine activities. People of this type have imaginative, impulsive and pure characteristics. The suitable occupations are related to paintings, written art, acting, and sculpture.

Besides information regarding the characteristics of respondents which is based on personality types in Table III, the data processing using SPSS also obtained information on the characteristics of other respondents. Mostly, the respondents were nature science major students, which the percentage was $69.7 \%$. In terms of gender, the percentage was approximately equal, the female respondents amounted to $59.8 \%$ and the male respondents by $40.2 \%$. Most of the respondents' fathers' educational background were S1, which amounted to $43.2 \%$, and most of the mothers' educational background were S1 and SMA (senior high school) which both percentages were $39.4 \%$. In terms of parent's income, $50 \%$ of the respondents' parents had relatively high monthly income, which were above 5 million rupiahs. Such high 
income was related to fathers' occupation variable, which the majority was entrepreneur by $39.4 \%$. Most of mothers' occupation were housewives which was by $43.9 \%$.

After the characteristics of respondents were gained, the next step was to conduct independence test between the independent/predictors variables $(\mathrm{X})$ and the dependent/response variables (Y) to find out the relationship between these variables. Then, cross tabulation was employed between the response variables and the predictor variables. The hypotheses used to test the independence between the predictor variables and the response variable were as follows.

$\mathrm{H} 0$ : there is no relationship between predictor variables and response variables

$\mathrm{H} 1$ : there is a relationship between predictor variables and response variables The research used the Chi-square test statistic. The test results are shown in Table 4 below.

Table 4. Independence Test Between Response And Predictor Variable

\begin{tabular}{lccc}
\hline \multicolumn{1}{c}{ Variable } & Chi-square value & P-value & Decision \\
\hline Major of Studies & 24.076 & 0.000 & Reject H0 \\
Gender & 23.793 & 0.000 & Reject H0 \\
Father's Education & 80.959 & 0.000 & Reject H0 \\
Mother's Education & 72.411 & 0.000 & Reject H0 \\
Parent's Income & 24.914 & 0.050 & Reject H0 \\
Father's occupation & 156.259 & 0.000 & Reject H0 \\
Mother's occupation & 58.287 & 0.001 & Reject H0 \\
\hline
\end{tabular}

Based on Table IV it is known that all the predictor variables which have relationship with the response variable Holland's Personality Type (Y) were the variable of Major of Studies $\left(\mathrm{X}_{1}\right)$, Gender $\left(\mathrm{X}_{2}\right)$, Father Educational Background $\left(\mathrm{X}_{3}\right)$, Mother Educational Background $\left(\mathrm{X}_{4}\right)$, Parent's Income $\left(\mathrm{X}_{5}\right)$, Father's Occupation $\left(\mathrm{X}_{6}\right)$ and Mother's Occupation $\left(\mathrm{X}_{7}\right)$.

\subsection{Holland's Personality Type Model}

In order to determine the factors that influence Holland's personality type, this research employed multinomial logistic regression method because the response variables have nominal data scale consisting of six categories. These six categories were response variables in this multinomial logistic regression method, while the predictor variables were those that have relationship with Holland's Personality Type response variables (Y), namely Major of Studies (X1), Gender (X2), Father Educational Background (X3), Mother Educational Background (X4), Parent's Income (X5), Father's Occupation (X6) and Mother's Occupation (X7).

Individual multinomial logistic regression includes individual parameter testing and parameter estimation. Using the Wald test, this research conducted individual testing to determine the significance of predictor variable parameters. If the parameter of a predictor variable was significant, thus the predictor variable would affect response variables. The hypotheses were as follows.

$$
\begin{aligned}
& H_{0}: \beta_{k}=0 \\
& H_{1}: \beta_{k} \neq 0 \text {, where } \mathrm{k}=1,2 . . \mathrm{p}
\end{aligned}
$$

This study used Wald test statistics. Using the comparison category, which was the conventional personality type, the analysis obtained the results as shown in Table 5. 
Table 5. Individual Predictor Variable Test

\begin{tabular}{lcc}
\hline \multicolumn{1}{c}{ Variable } & Chi-square value & P-value (sig.) \\
\hline Major of Studies & 33.879 & 0.0001 \\
Gender & 24.277 & 0.0001 \\
Father's Education & 85.533 & 0.0001 \\
Mother's Education & 79.207 & 0.0001 \\
Parent's Income & 28.323 & 0.0200 \\
Father's occupation & 140.057 & 0.0001 \\
Mother's occupation & 63.066 & 0.0001 \\
\hline
\end{tabular}

Table $\mathrm{V}$ shows that the variables used in individual multinomial logistic regression testing which are the variables of Major of Studies (X1), Gender (X2), Father Educational Background (X3), Mother Educational Background (X4), Parent's Income (X5), Father's Occupation (X6) and Mother's Occupation (X7) significantly influenced the Holland's Personality Type (Y). That was indicated by the p-value (sig.) in each predictor variable which was less than $\alpha$, where $\alpha$ is at 0.1 . Based on the results of data processing with the help of SPSS, the response probability function or multinomial logistic regression model for Senior High School Major of Studies predictor variables (X1) was related to the equation (8), (9), (10), (11) and (12) with the logit function as follows with conventional category as comparison.

Model for realistic type

Model for investigative type

$$
\mathrm{g}_{1}\left(\mathrm{X}_{1}\right)=-1,386-0,560 \mathrm{X}_{1}(1)
$$

Model for artistic type

$$
\mathrm{g}_{2}\left(\mathrm{X}_{1}\right)=0,118-21,486 \mathrm{X}_{1}(1)
$$

Model for social type

$$
\mathrm{g}_{3}\left(\mathrm{X}_{1}\right)=0,172+0,185 \mathrm{X}_{1}(1)
$$

Model for enterprising type

$$
\mathrm{g}_{4}\left(\mathrm{X}_{1}\right)=-0,208+0,747 \mathrm{X}_{1}(1)
$$

$$
\mathrm{g}_{5}\left(\mathrm{X}_{1}\right)=0,318+0,038 \mathrm{X}_{1}(1)
$$

After individual multinomial logistic regression was carried out, and predictor variables that significantly influenced the response variables had been obtained, Likelihood Ratio Test was carried out simultaneously to obtain predictor variables that simultaneously affected the response variables. The hypotheses in simultaneous testing are as follows.

$$
H_{0}: \beta_{1}=\beta_{1}=\ldots=\beta_{p}=0
$$

$$
H_{1} \text { : at least there is one } \beta_{k} \neq 0 \text {, where } \mathrm{k}=1,2 \ldots, \mathrm{p}
$$

Based on Table VI, Study Major $\left(\mathrm{X}_{1}\right)$, Gender $\left(\mathrm{X}_{2}\right)$, Father's Education $\left(\mathrm{X}_{3}\right)$, Mother's Education $\left(\mathrm{X}_{4}\right)$, Parents' Income $\left(\mathrm{X}_{5}\right)$, Father's Occupation $\left(\mathrm{X}_{6}\right)$ and Mother's Occupation $\left(\mathrm{X}_{7}\right)$ variables simultaneously has a significant effect on the response. The parameter estimates of the simultaneous testing above are shown in Table 6.

Table 6. Simultaneous Testing Of Predictors Variable

\begin{tabular}{lrrr}
\hline \multirow{2}{*}{ EFFECT } & \multicolumn{3}{c}{ LIKELIHOOD RATIO TESTS } \\
\cline { 2 - 4 } & Chi-square & df & Sig. \\
\hline Intercept & 14.777 & 5 & .011 \\
Department & 27.940 & 5 & .000 \\
\hline
\end{tabular}




\begin{tabular}{lrrr}
\hline Gender & 9.552 & 5 & .089 \\
Father's education & 19.521 & 5 & .002 \\
Mother's education & 28.045 & 5 & .000 \\
Parent's income & 16.382 & 5 & .006 \\
Father's occupation & 9.628 & 5 & .086 \\
Mother's occupation & 9.005 & 5 & .100 \\
\hline
\end{tabular}

Based on the results of data processing with SPSS, it can be seen that the odds ratio in logit 1 (realistic personality type):

1. For the social studies category, the value is 0.338 , which means that respondents from social science major have a chance 0.338 times bigger to have realistic personality types compared with respondents from science majors with assumption that other variables are constant.

2. The tendency of female respondents is 0.265 times more likely to have realistic personality type compared to male respondents with assumptions that the other variables are constant.

3. Respondents who have a father with a primary education are 71,361 times more likely to have a realistic personality type compared to the respondents with a father with other categories of education assuming other variables are constant. The tendency of respondents who have a father with a junior high school education to have a realistic personality type is 61,350 times more than the respondent with a father with other categories of education assuming other variables are constant. The tendency of respondents who have a father with a high school education to have a realistic personality type is 130,227 times bigger than the respondent with a father with other categories of education assuming other variables are constant. The tendency of respondents who have a father with a D3 final education to have a realistic personality type is 0.580 times more than the respondents with a father with other categories of education assuming other variables are constant. The tendency of respondents who have a father with a final education $\mathrm{S} 1$ to have a realistic personality type is 2,359 times higher than the respondent with a father with other categories of education assuming other variables are constant.

4. The tendency of respondents who have a primary school-educated mother to have a realistic personality type is 0.007 times greater than the respondents with mothers with other categories of education assuming other variables are constant. The tendency of respondents who have a junior high school-educated mother to have a realistic personality type is 0.017 times greater than the respondents with mothers with other categories of education assuming other variables are constant. The tendency of respondents who have a high school-educated mother to have a realistic personality type is 0.105 times greater than the respondents with a mother with other categories of education assuming other variables are constant. The tendency of respondents who have a D3-educated mother to have a realistic personality type is 0.027 times greater than the respondents with a mother with other categories of education assuming other variables are constant. The tendency of respondents who have a S1-educated mother to have a realistic personality type, is 0.190 times greater than the respondents with mothers from other categories of education assuming other variables are constant.

5. Respondents who have parents with income less than Rp. 1 million is 0.548 times more likely to have a realistic personality type than the respondents who have parents with other categories of income assuming other variables are constant. Respondents who have parents with income of Rp. 1 Million to Rp. 2.5 Million is 61,544 times more likely to have a realistic personality type than the respondents who have parents with other categories of income assuming other variables are constant. Respondents who have parents with income of Rp. 2.5 Million to Rp. 5 Million is 5.329 times more likely to have a realistic personality 
type than the respondents who have parents with other categories of income assuming other variables are constant.

6. The tendency of respondents whose fathers are civil servants to have realistic personality types is 81.410 times higher than respondents with fathers with other professions assuming other variables are constant. The tendency of respondents whose fathers are lecturers / teachers to have realistic personality type is 9,076 times higher than respondents with fathers with other professions assuming other variables are constant. The tendency of respondents whose fathers are doctors / nurses to have realistic personality type is 81,149 times higher than respondents with fathers with other professions assuming other variables are constant. The tendency of respondents whose fathers are police to have a realistic personality type is 13933,887 times higher than respondents with fathers with other professions assuming other variables are constant. The tendency of respondents whose fathers are state-owned company employees to have realistic personality type is 24,385 times higher than respondents with fathers with other profession assuming other variables are constant. The tendency of respondents whose fathers are private employees to have realistic personality types is 5420,849 times higher than respondents with fathers with other professions assuming other variables are constant. The tendency of respondents whose fathers were lawyers to have realistic personality types was 1078,468 times higher than respondents with fathers with other professions assuming other variables were constant. The tendency of respondents whose fathers are accountants to have realistic personality types was 53,316 times higher than respondents with fathers with other profession assuming other variables were constant. The tendency of respondents whose fathers are contractors to have realistic personality types is 2,258.10 ${ }^{302}$ times higher than respondents with fathers with other professions assuming other variables are constant. The tendency of respondents whose fathers are flight attendants to have realistic personality type is 3226,403 times higher than respondents with fathers with other professions assuming other variables are constant. The tendency of respondents whose fathers are sailors to have realistic personality type, was 18031,582 times higher than respondents with fathers with other profession assuming other variables were constant. The tendency of respondents whose fathers are self-employed to have realistic personality type is 8,338 times higher than respondents with fathers with other professions assuming other variables are constant. The tendency of respondents whose fathers are farmers to have realistic personality type is 0.224 times higher than respondents with fathers with other professions assuming other variables are constant.

7. The tendency of respondents whose mothers are civil servants to have a realistic personality type is 0.031 times higher than the respondents with other professions with the assumption that other variables are constant. The tendency of respondents whose mothers are doctors / nurses to have realistic personality type is 0.357 times higher than respondents with mothers of other professions assuming other variables are constant. The tendency of respondents whose mothers are state-owned company employees to have realistic personality types is 0.166 times higher than respondents with other profession mothers assuming other variables are constant. The tendency of respondents whose mothers are private employees to have personality types realistic is 0.920 times higher than respondents with other professionals with the assumption that other variables are constant. The tendency of respondents whose mothers are self-employed to have a realistic personality type is 0.132 times higher than the respondents with other professions with the assumption that other variables are constant. The tendency of respondents whose mothers are housewives) to have realistic personality types was 0.010 times higher than respondents with mothers of other professions assuming other variables were constant. 
The simultaneous probability function or multinomial logistic regression function resulting from parameter estimates that have been carried out is in accordance with equations (8), (9), (10), (11) and (12) with the logit function as follows.

Models for realistic types:

$\mathrm{g}_{1}\left(\mathrm{X}_{1}\right)=-1.218-1.086 \mathrm{X}_{1}(1)-1.329 \mathrm{X}_{2}(1)+4.268 \mathrm{X}_{3}(1)+4.117 \mathrm{X}_{3}(2)+4.869 \mathrm{X}_{3}(3)$

$-0.545 \mathrm{X}_{3}(4)+0.932 \mathrm{X}_{3}(5)-5.017 \mathrm{X}_{4}(1)-4.081 \mathrm{X}_{4}(2)-2.258 \mathrm{X}_{4}(3)-3.602 \mathrm{X}_{4}(4)$

$1.661 \mathrm{X}_{4}(5)-0.602 \mathrm{X}_{5}(1)+4.120 \mathrm{X}_{5}(2)+1.673 \mathrm{X}_{5}(3)+4.400 \mathrm{X}_{6}(1)+2.206 \mathrm{X}_{6}(2)+$

$4.396 \mathrm{X}_{6}(3)+9.542 \mathrm{X}_{6}(4)+3.194 \mathrm{X}_{6}(5)+8.598 \mathrm{X}_{6}(6)+6.983 \mathrm{X}_{6}(7)+3.976 \mathrm{X}_{6}(8)+$

$696.195 \mathrm{X}_{6}(9)+8.079 \mathrm{X}_{6}(10)+9.800 \mathrm{X}_{6}(11)+2.121 \mathrm{X}_{6}(12)-1.497 \mathrm{X}_{6}(13)-3.486$

$\mathrm{X}_{7}(1)-1.030 \mathrm{X}_{7}(3)-1.794 \mathrm{X}_{7}(5)-0.084 \mathrm{X}_{7}(6)-2.023 \mathrm{X}_{7}(12)-4.631 \mathrm{X}_{7}(14)$

In the same way, a model for investigative, artistic, social and enterprising types will be obtained.

\subsection{Accuracy of Model Classification}

The accuracy of the classification obtained from the model is shown in Table 7 below.

Table 7. Accuracy Of Model Classification

\begin{tabular}{crrrrrrrr}
\hline \multirow{2}{*}{ OBSERVED } & \multicolumn{7}{c}{ PREDICTED } \\
\cline { 2 - 9 } & \multicolumn{1}{c}{ R } & \multicolumn{1}{c}{ I } & \multicolumn{1}{c}{ S } & \multicolumn{1}{c}{ E } & \multicolumn{1}{c}{ C } & CORRECT \\
\hline R & 2 & 0 & 4 & 0 & 4 & 0 & $20.0 \%$ \\
I & 0 & 22 & 6 & 0 & 6 & 2 & $61.1 \%$ \\
A & 0 & 10 & 18 & 16 & 12 & 2 & $31.0 \%$ \\
S & 0 & 6 & 10 & 18 & 14 & 2 & $36.0 \%$ \\
E & 0 & 8 & 8 & 4 & 42 & 2 & $65.6 \%$ \\
C & 0 & 0 & 10 & 10 & 18 & 8 & $17.4 \%$ \\
Overall & $0.8 \%$ & 17.4 & 21.2 & 18.2 & 36.4 & 6.1 & $41.7 \%$ \\
\hline
\end{tabular}

Table VII shows that the classification accuracy of the model is 41.7 percent. It shows that the number of predictions which matched the actual conditions (observation) was 41.7 percent. It also shows that the misclassification was 58.3 percent. It can be observed in Table VII that $20 \%$ of realistic type respondents was correctly predicted by the model so that there are as many as $80 \%$ respondents belonged to realistic type categories who were misclassified into other categories. Based on the observation, $61.1 \%$ of the investigative type respondents were correctly predicted by the model so that there are as many as $38.9 \%$ of investigative type respondents who were misclassified into other categories. Based on the observation, the model correctly predicted $31 \%$ of the artistic type respondents. Therefore, there were $69 \%$ of the artistic type category respondents who were incorrectly classified into other categories. Based on the observation, $36 \%$ of the social type respondents were correctly predicted by the model so that there are as many as $64 \%$ of the social type categories who were incorrectly classified into other categories. The model correctly predicted $65,5 \%$ of the enterprising type respondents. Therefore, there were $34.4 \%$ of enterprising type categories which were classified into other categories. Finally, 17,4\% conventional type respondents were correctly predicted by the model so that there were $82.6 \%$ conventional type respondents who were misclassified into other categories.

Although the overall parameters are significant at $\alpha=0.1$, the classification accuracy is less than $50 \%$. This may be caused by the lack of representative predictor variables for modelling the Holland personality type or inappropriate selection of model. 


\section{Conclussion}

Based on data analysis and discussion, it was concluded that the majority of respondents were classified into enterprising (24.2\%) and artistic (22\%) personality types. Most respondents $(69.7 \%)$ were from science majors. The proportion of gender was approximately the same; $59.8 \%$ of the students were female and $40.2 \%$ were male. Most of the respondents' fathers were graduated from S1 $(43.2 \%)$, while the mothers were majority S1 and senior high school graduates with the same percentage of $39.4 \%$. Regarding the parents' income, $50 \%$ of respondents' parents had high monthly income of above 5 million. The high income was dominantly obtained from respondents whose fathers were entrepreneurs (39.4\%) while the mothers were mostly housewives (43.9\%).

Based on the individual multinomial logistic regression test, it could be observed that all predictor variables namely, Major of studies (X1), Gender (X2), Father's Education (X3), Mother's Education (X4), Parent's Income (X5), Father's Occupation (X6) and Mother's Occupation (X7) significantly influence the Holland Personality Type (Y) at the error level $(\alpha)$ 0.1 .

Multinomial logistic regression model for Holland student personality type resulted in classification accuracy of only $41.7 \%$. The low accuracy of classification may be due to a lack of predictor variables that were representative for modelling the students' Holland personality type or due to less appropriate selection of model.

\section{References}

[1] J. S. Eccles, "Understanding Women's Educational and Occupational Choices: Applying the Eccles Et Al. Model of Achievement-Related Choices," Psychol. Women Q., vol. 18, pp. 585-609, 1994.

[2] A. Irwan, Sangkan Paran Gender. pustaka pelajar, 1997.

[3] R. Lippa, "Gender-Related Individual Differences and the Structure of Vocational Interests: The Importance of the People-Things Dimension,” J. Pers. Soc. Psychol., vol. 74, p. 996, 1998.

[4] N. I. Subono, "Laki-Laki, Kekerasan Gender Dan Feminisme," Fem. Laki-laki Solusi atau Persoalan, 2001.

[5] A. N. P. Murniati, Getar Gender: Perempuan Indonesia Dalam Perspektif Agama, Budaya, Dan Keluarga. Magelang: Indonesiatera, 2004.

[6] S. O. Salami, "Roles of Personality, Vocational Interests, Academic Achievement and SocioCultural Factors in Educational Aspirations of Secondary School Adolescents in Southwestern Nigeria," Career Dev. Int., vol. 13, pp. 630-47, 2008.

[7] M. Vock, O. Köller, and G. Nagy, "Vocational Interests of Intellectually Gifted and Highly Achieving Young Adults,” Br. J. Educ. Psychol., vol. 83, pp. 305-28, 2013.

[8] E. S. Weisgram, R. S. Bigler, and L. S. Liben, "Gender, Values, and Occupational Interests among Children, Adolescents, and Adults," Child Dev., vol. 81, pp. 778-96, 2010.

[9] H. Herdiansyah, Gender Dalam Perspektif Psikologi. Salemba Humanika, 2016.

[10] S. Perkmen and S. Sahin, "Who Should Study Instructional Technology? Vocational Personality Approach,” Br. J. Educ. Technol., vol. 44, pp. 54-65, 2013.

[11] H. Korpershoek, H. Kuyper, and M. Van der Werf, "The Role of Personality in Relation to Gender Differences in School Subject Choices in Pre-University Education,” Sex Roles, vol. 67, pp. 630-45, 2012.

[12] M. L. Savickas and A. R. Spokane, Vocational Interests: Meaning, Measurement, and Counseling Use. Davies-Black Publishing, 1999.

[13] C. T. Schuette, M. K. Ponton, and M. L. Charlton, "Middle School Children's Career Aspirations: Relationship to Adult Occupations and Gender," Career Dev. Q., vol. 60, pp. 36-46, 2012. 
[14] S. L. Turner, J. Conkel, M. T. Starkey, and R. Landgraf, "Relationships among Middle-School Adolescents' Vocational Skills, Motivational Approaches, and Interests," Career Dev. Q., vol. 59, pp. 154-68, 2010.

[15] J. L. Holland, Making Vocational Choices: A Theory of Vocational Personalities and Work Environments. Psychological Assessment Resources, 1997.

[16] J. L. Holland, Vocational Preference Inventory. Consulting Psychologists Press, 1985.

[17] A. Al-Hibri, Wanita Dalam Masyarakat Indonesia. Yogyakarta: Sunan Kalijaga Press, 2001.

[18] J. C. Smart, K. A. Feldman, and C. A. Ethington, "Holland's Theory and Patterns of College Student Success," in Commissioned report for the national symposium on postsecondary student success: Spearheading a dialog on student success, 2006.

[19] H. Djaali, Psikologi Pendidikan. Jakarta: Program Pascasarjana-Universitas Negeri Jakarta, 2009. [20] D. K. Sukardi, Bimbingan dan Konseling. Bina Aksara, 1988.

[21] W. Winkel and S. Hastuti, Bimbingan Konseling Di Institusi Pendidikan, Edisi Revi. Jakarta: grasindo, 2010.

[22] S. Bruce and S. C. Stone, Fundamentals of Guidance. Boston: Houghton Mifflin, 1981.

[23] K. Z. Deniz, E. Türe, A. Uysal, and T. Akar, "Investigation of Vocational Interest and Preference in Terms of Gender and Socio-Economic Status," Eurasian J. Educ. Res., 2014.

[24] L. M. Dinella, M. Fulcher, and E. S. Weisgram, "Sex-Typed Personality Traits and Gender Identity as Predictors of Young Adults' Career Interests," Arch. Sex. Behav., vol. 43, pp. 493-504, 2014.

[25] N. Kaushik and A. Chaudhary, "Impact of Level of Education on Attitude Towards Modernity and Vocational Interest," Gyanodaya J. Progress. Educ., vol. 4, 2011.

[26] J. L. Holland, “A Theory of Vocational Choice," J. Couns. Psychol., vol. 6, p. 35, 1959.

[27] F. D. Kentli, "Perceived Influences in Vocational Preference of Turkish High School Students," J. Kirsehir Educ. Fac., vol. 15, 2014.

[28] K. P. Y. Liu and C.-S. Wong, "Career Maturity and Job Attainment: The Moderating Roles of Emotional Intelligence and Social Vocational Interest,” Int. J. Educ. Vocat. Guid., vol. 14, pp. $293-$ 307, 2014.

[29] S. H. Osipow, Theories of Career Development. A Comparison of the Theories. 1968.

[30] D. Cervone and L. A. Pervin, Personality: Theory and Research, 10 th ed. 2008.

[31] D. W. H. Jr, S. Lemeshow, and R. X. Sturdivant, Applied Logistic Regression. John Wiley \& Sons, 2013. 